\title{
Indirect Evidence for \\ Cell Wall and Membrane:Differences between Filamentous Swarming Cells and Short Non-swarming Cells of Proteus mirabilis
}

\author{
By JUDITH P. ARMiTAGE, R. J. ROWBURY AND D. G. SMITH \\ Department of Botany and Microbiology, University College London, \\ London $W C_{\mathrm{I}} E 6 B T$
}

\section{(Received Io February 1975; revised 6 March 1975)}

The bacterial wall and cytoplasmic membrane have been implicated in the processes of DNA synthesis and cell division (Shapiro et al. 1970; Inouye \& Pardee, 1970; Wu \& Pardee, 1973). Much of the evidence for such a relationship comes from work on mutants defective in various stages of cell division. Wild-type Proteus mirabilis, when grown on many solid media, undergoes a cyclic inhibition of cell division as part of the phenomenon known as swarming (Smith, 1972). During this process non-septate, multinucleate, highly flagellate cells up to $80 \mu \mathrm{m}$ long are produced. These move across the agar surface several millimetres away from the main colony, probably due to a negative chemotactic response, before dividing to give normal, sparsely flagellate, short rods. The process is repeated a few hours later until the agar surface is covered.

To establish whether any alteration in the properties of the wall or the cytoplasmic membrane occurred during this cyclic process, some properties of long, swarming cells from agar, short cells from swarm-inhibiting solid media, and exponential broth-grown cells have been compared. The agar-grown short cells were growing under physically similar conditions to the swarmers, whereas the exponential broth-grown short cells may have been in a metabolically more similar condition to the rapidly growing swarm cells.

\section{METHODS}

Organism. The strain of Proteus mirabilis used was an isolate from University College Hospital.

Media and growth measurement. Oxoid Nutrient Broth No. 2 was used in all experiments except for those on amino acid uptake, for which the minimal medium of Grabow \& Smit (1967) was used, with the addition of $0.15 \% \mathrm{NaCl}$ to allow swarming. For solid media $1 \cdot 75 \%$ (w/v) Bacto-agar (Difco) was added, and for the swarm-inhibiting media $I \%(w / v)$ activated charcoal was added to the above (Alwen \& Smith, 1967). The media were inoculated from a $24 \mathrm{~h}$ broth culture and all were incubated for $18 \mathrm{~h}$ at $30^{\circ} \mathrm{C}$.

The long, swarming cells were isolated soon after they were generated at the edge of the colony, by cutting the non-swarming inner part of the centrally inoculated colony from the agar and then washing the swarming cells off with the appropriate experimental medium. Sizing with a Coulter Counter model F (Coulter Electronics Ltd, Dunstable, Bedfordshire) showed that this procedure gave suspensions with at least $80 \%$ of the cells longer than the non-swarming cells. Agar-grown, non-swarming cells were washed off using the same experimental media as for the swarming cells. 
Growth of liquid cultures was measured by following the extinction of cell suspensions using a Hilger colorimeter and cell numbers were followed using the Coulter Counter. All results have been expressed in terms of $\mathrm{mg}$ dry wt cells, to allow for differences in extinction due to the different scattering properties of the long and short cells.

Estimation of leakage. The leakage of pentose sugars and amino acids from washed cells (about $300 \mu \mathrm{g}$ dry wt $/ \mathrm{ml}$ ) into sterile, deionized water was measured chemically. Leakage of pentose sugars was determined by means of the orcinol reaction (Herbert, Phipps \& Strange, I97I), measuring $E_{660}$, and that of amino acids by the ninhydrin assay (Rosen, 1957), measuring $E_{570}$.

Active uptake of amino acids. Changes in the active transport process were measured by following the uptake of a labelled amino acid using the method of Tristram \& Neale (I968). The uptake of $0.025 \mu \mathrm{Ci}\left[{ }^{14} \mathrm{C}\right]$ proline/ml (Radiochemical Centre, Amersham, Buckinghamshire) at $20^{\circ} \mathrm{C}$ was measured by incubating washed organisms $(200 \mu \mathrm{g}$ dry wt $/ \mathrm{ml})$ in minimal medium (Grabow \& Smit, 1967 ) to which was added I $50 \mu \mathrm{g}$ chloramphenicol $/ \mathrm{ml}$ to inhibit incorporation of the amino acids into protein. Samples $(\mathrm{I} \cdot 0 \mathrm{ml})$, taken at $30 \mathrm{~s}$ intervals, were filtered directly through Millipore filters $(0.65 \mu \mathrm{m}$ pore, $23 \mathrm{~mm}$ diameter) with $2 \mathrm{ml}$ ice-cold minimal medium. The radioactivities in the dried filters were counted on a Scaler I 700 .

Sensitivity to antibacterial agents. Gram-negative bacteria are normally relatively insensitive to rifampicin (Normark, I970). To measure sensitivity to this agent the incorporation of $\left[2-{ }^{14} \mathrm{C}\right]$ uracil (Radiochemical Centre) into RNA was measured in the presence of $50 \mu \mathrm{g}$ rifampicin $/ \mathrm{ml}$. All three cell types were resuspended in fresh nutrient broth to a standard extinction (equivalent to about $100 \mu \mathrm{g}$ dry $\mathrm{wt} / \mathrm{ml}$ ) and the rifampicin added with $0.2 \mu \mathrm{Ci}$ $\left[2-{ }^{14} \mathrm{C}\right]$ uracil $/ \mathrm{ml}$. Samples $(0.2 \mathrm{ml})$ were collected at intervals directly on Whatman filter papers. These were then placed in ice-cold $5 \%(\mathrm{w} / \mathrm{v})$ trichloroacetic acid (TCA) containing 100 $\mu \mathrm{g}$ unlabelled uracil $/ \mathrm{ml}$. The filters were washed twice with $5 \%(\mathrm{w} / \mathrm{v})$ TCA and once each in ether-ethanol $(\mathrm{I}: \mathrm{I}, \mathrm{v} / \mathrm{v})$ and ether. After the filters had been dried, the radioactivity was measured by placing them in $15 \mathrm{ml}$ toluene scintillant containing $0.6 \%(\mathrm{w} / \mathrm{v})$ butyl PBD (Ciba) and counting in a Packard Tricarb liquid scintillation spectrometer.

Sensitivity to deoxycholate. Sensitivity to the surfactant sodium deoxycholate was measured by following the growth rate in broth at $30{ }^{\circ} \mathrm{C}$ in the presence of different concentrations of the compound. The threshold dose was the minimum at which there was no increase in extinction with time.

\section{RESULTS AND DISCUSSION}

To ascertain whether there are envelope differences between swarming and non-swarming cells we investigated the permeability of the organisms by a number of methods and determined their sensitivity to a surface-active agent. All experiments indicated some wall or membrane difference between swarming cells and non-swarming, exponential and agargrown cells (Table I).

Leakage of amino acids and pentose sugars from the swarming cells was two to three times as great as from the short cells. This was initially thought to be due to the lower viability reported for swarming cells (Hughes, 1957), but with the strain and harvesting conditions used here all swarming cells were viable as judged by their ability to form colonies on nutrient agar. Moreover, through the experimental period of up to $2 \mathrm{~h}$ there was no loss of viability.

Not only was leakage greater from swarmers but amino acid uptake was also reduced. 
Table I. Indications of wall or membrane differences between long, swarming and short, non-swarming cells of $P$. mirabilis

\begin{tabular}{|c|c|c|c|c|c|}
\hline Cell type & $\begin{array}{l}\text { Pentose } \\
\text { leakage* }\end{array}$ & $\begin{array}{c}\text { Amino acid } \\
\text { leakage } \dagger\end{array}$ & $\begin{array}{l}\text { Proline } \\
\text { uptake }\end{array}$ & $\begin{array}{l}\text { Rifampicin } \\
\text { inhibition } \S\end{array}$ & $\begin{array}{l}\text { Deoxycholate } \\
\text { resistance|| }\end{array}$ \\
\hline swarming cells & $4^{\circ} 0$ & $15 \cdot 9$ & 258 & $51 \cdot 5$ & $\mathbf{I} \cdot \mathbf{I}$ \\
\hline $\begin{array}{l}\text { ential broth- } \\
\text { n cells }\end{array}$ & $2 \cdot 0$ & $5 \cdot 4$ & 406 & $22 \cdot 3$ & $2 \cdot 2$ \\
\hline $\begin{array}{l}\text { warming agar- } \\
\text { n cells }\end{array}$ & $2 \cdot 5$ & $4 \cdot 5$ & 666 & $26 \cdot 2$ & $4 \cdot 8$ \\
\hline
\end{tabular}

\footnotetext{
* Leakage of pentose sugars as measured by $E_{660}$ using the orcinol reaction. Results expressed as $\mu \mathrm{g} / \mathrm{mg}$ dry wt cells/h.

$\dagger$ Leakage of amino acids as measured by $E_{570}$ using the ninhydrin assay. Results expressed as $\mu \mathrm{g} / \mathrm{mg}$ dry wt cells/h.

$\ddagger$ Uptake of $\left[{ }^{14} \mathrm{C}\right]$ proline at $20{ }^{\circ} \mathrm{C}$, expressed as c.p.m. $/ \mathrm{min} / \mathrm{mg}$ dry wt cells.

$\S$ Rifampicin inhibition is expressed as percentage reduction in incorporation of $\left[2-{ }^{14} \mathrm{C}\right]$ uracil into RNA in the presence of rifampicin $(5 \mu \mathrm{g} / \mathrm{ml})$.

II Deoxycholate resistance was measured as the concentration $(\%, w / v)$ required for complete growth inhibition.
}

The uptake of $\left[{ }^{14} \mathrm{C}\right]$ proline into the amino acid pool showed a marked reduction in long cells as compared with the other cell types. This difference may have been due to a change in the envelope structure that affected the active transport processes, although it is possible that uptake might be mainly at the cell poles.

Measurement of other properties related to permeability also indicated an envelope change in swarmers; for example, they were more permeable to rifampicin. This agent, at $5 \mu \mathrm{g} / \mathrm{ml}$, reduced incorporation of $\left[{ }^{2-14} \mathrm{C}\right]$ uracil into swarming cells by about $50 \%$, but reduced incorporation into the short cells by only about $25 \%$. This suggests a possible change in the barrier properties of the outer membrane, because in Gram-negative bacteria the outer membrane layer provides the permeability barrier to large molecules including antibacterial agents such as rifampicin and actinomycin D (Leive, I965; Normark, 1970). Preliminary experiments suggested that swarmers are also more permeable to actinomycin D (data not shown).

Sodium deoxycholate is a surfactant whose mode of action is generally assumed to be disruption of the interaction between phospholipids and other components of the cell wall and membrane (Nagel de Zwaig \& Luria, 1967; Hirota, Mordoh \& Jacob, 1970). The sensitivity of the cell to deoxycholate is taken as a measure of the accessibility of these components and the strength of their binding within the wall and membrane. The concentration of deoxycholate required completely to inhibit the growth of the swarming cells was half that needed to inhibit the broth-grown, short cells and a quarter that needed to inhibit the growth of the agar-grown, short cells. At concentrations below the lethal threshold there was always a greater reduction in the growth rate of the swarming cells and there was an initial lysis of about $25 \%$ of the cells not seen in the other two growth types.

The experiments described showed that as well as a difference between the long, swarming cells and the short cells there was also a difference between the two types of short cells. This was not unexpected, as it is known that there are measurable differences in wall composition between cells grown under different conditions (Cronan \& Vagelos, 1972; Ballesta \& Schaechter, 1971; Starka \& Moravova, 1970).

Although none of the experiments described proves conclusively that there is a wall or membrane change, all point towards an alteration in the envelope layer or layers of 
$P$. mirabilis and work is in progress to establish which components are involved. If this change proves to be a cause rather than a result of the natural inhibition of cell division in $P$. mirabilis, it may help to establish whether there is a wall or membrane component necessary for septation which is lacking in the non-dividing swarmer.

One of us (J.P.A.) thanks the S.R.C. for financial support.

\section{REFERENCES}

Alwen, J. \& Smith, D. G. (1967). Medium to suppress swarming in Proteus. Journal of Applied Bacteriology 30, 389-394.

Ballesta, T. P. \& Schaechter, M. (1971). Effect of shift-down and growth inhibition on phospholipid metabolism of Escherichia coli. Journal of Bacteriology 107, $25 \mathrm{I}-258$.

Cronan, J. E., Jun. \& Vagelos, P. R. (1972). Metabolism and function of the membrane phospholipid of Escherichia coli. Biochimica et biophysica acta 265, 25-60.

Grabow, W. O. K. \& Smit, J. A. (1967). Methionine synthesis in Proteus mirabilis. Journal of General Microbiology 46, 47-57.

Herbert, D., Phipps, P. J. \& Strange, R. E. (I97I). Chemical analysis of microbial cells. In Methods in Microbiology, vol. 5B, pp. 209-344. Edited by J. R. Norris and D. W. Ribbons. London and New York: Academic Press.

Hirota, V., Mordoh, J. \& JACOB, P. (1970). On the progress of cellular division in Escherichia coli. III. Thermosensitive mutants of Escherichia coli altered in the process of DNA initiation. Journal of Molecular Biology 53, 369-387.

Hughes, W. H. (1957). A reconsideration of swarming in Proteus mirabilis. Journal of General Microbiology I7, 49-58.

INOUYE, M. \& PARDEE, A. B. (1970). Changes in membrane proteins and their relation to DNA synthesis and cell division of Escherichia coli. Journal of Biological Chemistry 245, 5813-5819.

LeIVE, L. (1965). A non-specific increase in permeability in Escherichia coli produced by EDTA. Proceedings of the National Academy of Sciences of the United States of America 53, 745-750.

NAGEL DE ZWAIG, R. \& LURIA, S. E. (1967). Genetics and physiology of colicin-tolerant mutants of Escherichia coli. Journal of Bacteriology 94, I I I 2-I 123.

Normark, S. (1970). Genetics of a chain-forming mutant of Escherichia coli. Genetical Research $\mathbf{1 6}, 63-78$.

Rosen, H. (1957). A modified ninhydrin colorimeter analysis for amino acids. Archives of Biochemistry and Biophysics 67, 10-15.

Smith, D. G. (1972). The Proteus swarming phenomenon. Science Progress (Oxford) 60, 487-506.

Shapiro, B. M., SicCardi, A. G., Hirota, Y. \& Jacob, F. (1970). On the process of cellular division in Escherichia coli. Journal of Molecular Biology 52, 75-89.

Starka, J. \& Moravova, J. (1970). Phospholipids and cellular division of Escherichia coli. Journal of General Microbiology 60, 251-257.

Tristram, H. \& Neale, S. (1968). The activity and specificity of the proline permease in wild-type and analogue-resistant strains of Escherichia coli. Journal of General Microbiology 50, I 2 I-1 37.

Wu, P. C. \& PARdeE, A. B. (1973). Cell division of Escherichia coli: control by membrane organisation. Journal of Bacteriology Ir4, 603-6II. 